\title{
FINANSYZACJA GOSPODARKI KRAJÓW EUROPY ŚRODKOWO-WSCHODNIEJ
}

\section{WSTĘP}

Jednym z zagadnień, na które zwraca uwage środowisko ekonomiczne w ocenie obecnego stadium rozwoju gospodarki rynkowej, jest finansyzacja ${ }^{1}$, zamiennie określana takimi terminami, jak²: „finansjalizacja”, „ufinansowienie”, „giełdyzacja”, „bankokracja” czy „kapitalizm finansowy”. Te różnorodne nazwy omawianego procesu społeczno-ekonomicznego opisuja postępująca dominację sektora finansowego oraz jego podmiotów nad działalnościa pozostałych jednostek ekonomicznych ${ }^{3}$ oraz charakteryzują mechanizmy oddziaływania sfery finansowej na sferę realną gospodarki. W najbardziej opisowej definicji finansyzacji można przeczytać, że rozumiana jest ona jako wzrost: branży finansowej w całokształcie działalności ekonomicznej, aktywów finansowych w sumie aktywów całkowitych, zbywalnych papierów wartościowych w ogólnej wartości aktywów finansowych, roli rynku kapitałowego w przebiegu cykli koniunkturalnych ${ }^{4}$. Uważa się, że jest to nowy etap rozwoju kapitalizmu, w którym podstawowym źródłem osiagania dochodów sa inwestycje finansowe ${ }^{5}$. Twierdzi się również, że jest to jedna z ekonomicznych „płyt tektonicznych”, „podskórnych sił przemian” ostatnich kilkudziesięciu lat, będąca przerostem, wynaturzeniem sektora finansowego, czemu towarzyszy drastyczne skracanie horyzontu w decyzjach gospodarczych i zanik kultury myślenia strategicznego ${ }^{6}$, co powoduje inflację rynków kapitałowych prowadzącą do

${ }^{1} \mathrm{~W}$ pierwszych publikacjach używano najczęściej terminu „finansjalizacja”, będącego kalka językową angielskiego słowa financialization. Nieco później zaczał dominować termin „finansyzacja”, który będzie również obowiązywać w tym opracowaniu. W tak przetłumaczonym słowie financialization widoczna jest analogia do translacji z języka angielskiego innych zjawisk społeczno-gospodarczych. Przykładowo, termin finansowy securitization jest powszechnie określany w Polsce jako „sekurytyzacja”.

${ }^{2}$ Podano za: M. Ratajczak, Finansyzacja gospodarki, „Ekonomista” 2012, nr 3, s. 282.

3 A. Kamela-Sowińska, Od rachunkowości do opisu gospodarczego, „Zeszyty Teoretyczne Rachunkowości”, t. 77 (133), Stowarzyszenie Księgowych w Polsce, Warszawa 2014, s. 111.

${ }^{4}$ R. Dore, Stock Market Capitalism: Welfare Capitalism: Japan and Germany versus the Anglo-Saxons, 3rd ed., Oxford University Press, Oxford 2008, s. 19.

${ }^{5}$ M. Ratajczak, Kryzys finansowy a rozwój ekonomii jako nauki, w: W. Przybylska-Kapuścińska (red.), Studia z bankowości centralnej i polityki pieniężnej, Difin, Warszawa 2009.

${ }^{6}$ E. Mączyńska, Eamane obietnice jako syndrom nieładu instytucjonalnego, „Finanse, Rynki Finansowe, Ubezpieczenia”, nr 62, Zeszyty Naukowe Uniwersytetu Szczecińskiego nr 766, Szczecin 2013 , s. 2 . 
nadmiernej kapitalizacji przedsiębiorstw w krótkim czasie ${ }^{7}$, niepotwierdzanej w fundamentach ekonomicznych ich funkcjonowania.

Za początek finansyzacji uważa się koniec lat siedemdziesiątych i lata osiemdziesiąte XX w. ${ }^{8}$ Od początku lat siedemdziesiątych zaczęła przemijać era dobrobytu, złotego wieku kapitalizmu, okresu stabilnego wzrostu ${ }^{9}$. Rosnace wydatki rządowe na realizację rozbudowywanych programów społecznych czy też tworzenie przez przedsiębiorstwa złożonych systemów płacowych przyniosły kres możliwościom utrzymywania niskiej inflacji. Nastapił gwałtowany spadek realnych stóp procentowych, który w konsekwencji przyczynił się do obniżenia rentowności sektora finansowego. W celu jej poprawy instytucje finansowe zaczęły wprowadzać szereg coraz bardziej złożonych produktów finansowych, co nałożyło się na okres wdrażania deregulacji systemów i rynków finansowych. Zaakceptowane zostały przez rynek aktywa umożliwiające prowadzenie alokacji środków finansowych w ryzyko, co doprowadziło w konsekwencji do wystapienia kryzysów o podłożu finansowym. Na skutek finansyzacji najbardziej rozwinięte gospodarki świata pogrążyły się w kryzysie instytucji, regulacji, teorii ekonomicznych czy nawet modeli rozwoju społecznego ${ }^{10}$.

$\mathrm{Na}$ zachodzace procesy autonomizacji sektora finansowego i osiagania przezeń nadmiernej przewagi w gospodarce zaczęto zwracać większą uwagę od ostatniego globalnego kryzysu finansowego z 2008 r. W konsekwencji finansyzacja jest zagadnieniem stosunkowo mało rozpowszechnionym w literaturze i na gruncie ekonomii światowej budzi skrajnie odmienne opinie - od pełnej akceptacji po całkowite jej odrzucenie.

W pracach dotyczących finansyzacji, obok dyskusji związanych z próbami określenia jej istoty, przejawów oraz wymiaru historycznego, coraz istotniejsza rolę odgrywają analizy skali tego zjawiska i jego wpływu na funkcjonowanie oraz stabilność ekonomiczna, głównie gospodarek wysoko rozwiniętych. Spotkać można studia empiryczne dotyczące poziomu finansyzacji grupy państw, np. skupionych w OECD ${ }^{11}$. Z kolei gospodarki wschodzace, w tym kraje Europy Środkowo-Wschodniej (EŚW), nie doczekały się jeszcze głębszych studiów empirycznych na temat skali finansyzacji oraz jej wpływu na rozwój i stabilność gospodarki ${ }^{12}$. Należy mieć świadomość, że analizy empiryczne wpływu finansyzacji na funkcjonowanie gospodarki nie są łatwe, a wyniki badań sa

\footnotetext{
${ }^{7}$ J. Toporowski, Ekonomia i kultura finansyzacji, „Nowe Życie Gospodarcze” 2008, nr 8.

${ }^{8}$ Ł. Klimczak, Neoliberalizm i keynesizm w polityce gospodarczej: lekcje z kryzysu, „Nierówności Społeczne a Wzrost Gospodarczy”, z. 30, WN UR, Rzeszów 2013, s. 389.

${ }^{9}$ G. Epstein, Financialization, Rentier Interests, and Central Bank Policy, Manuscript, Department of Economics, University of Massachusetts, Amherst (MA), December 2001, s. 77.

${ }^{10}$ P. Dembinski, Finansjalizacja. Klęska urodzaju $w$ gospodarce, http://m.obserwatorfinansowy.pl/forma/debata/finansjalizacja-kleska-urodzaju-w-gospodarce [dostęp: 24.01.2012].

${ }^{11}$ Por. J. Assa, Financialization and its consequences: the OECD experience, „Finance Research" 1(1), 2012; B. Kus, Financialization and income inequality in OECD nations: 1995-2007, „The Economic and Social Review” 43(4), 2012, s. 477-495.

${ }^{12}$ Pojawiaja się pojedyncze studia empiryczne na temat finansyzacji w wybranych gospodarkach wschodzących, np.: J. L. Montenegro, V. S. Gasca, The Financialization of the Mexican Economy: 1993-2013, XIV International Business and Economy Conference, Bangkok, Thailand, 5-8 January 2015; S. Sen, Z. DasGupta, Financialization and Company Investment in India, Levy Economics Institute of Bard College, January 2015; I. Tellalbasi, F. Kaya, Financialization of Turkey industry sector, „International Journal of Financial Research” 4(3), 2013, s. 127-143.
} 
niejednoznaczne, głównie z racji wielości hipotez teoretycznych tłumaczących charakter powstających zależności oraz liczby wskaźników wykorzystywanych do pomiaru skali i natężenia tego zjawiska. Przede wszystkim nie sposób jest jednoznacznie stwierdzić, czy finansyzacja jest przyczyną i źródłem zmian w gospodarce, czy raczej jest ich skutkiem, lub szerzej - rezultatem adaptowania systemów finansowych do zmian zachodzacych w sferze realnej ${ }^{13}$.

Celem opracowania jest próba oceny stopnia finansyzacji gospodarek wybranych krajów EŚW, co pozwoli uzyskać odpowiedź o skali tego zjawiska i jego natężenia w badanych państwach w rozpatrywanym czasie oraz umożliwi wyodrębnienie przyczyn powstawania różnic w poziomie ich ufinansowienia. Rezultaty badawcze mogą być następnie zestawiane w analizach komparatystycznych z wynikami oceny stopnia finansyzacji gospodarek krajów wysoko rozwiniętych.

\section{II. ŹRÓDŁA, PRZEJAWY I SKUTKI FINANSYZACJI}

Za podstawowe przesłanki finansyzacji gospodarki uważa się przede wszystkim: deregulację systemu finansowego, procesy koncentracji w sektorze finansowym, rosnaca wielkość i udział na rynku finansowym inwestorów instytucjonalnych, dominację neoliberalnego modelu polityki pieniężnej, fiskalnej i gospodarczej ${ }^{14}$. Spośród podanych deregulacja wskazywana jest jako przesłanka nadrzędna, gdyż dzięki likwidacji kontroli udzielania kredytów, deregulacji stopy procentowej, ograniczenia barier w dostępie do usług finansowych, zmniejszania zakresu regulacji sektora finansowego ${ }^{15}$ nastapiła istotna zmiana charakteru funkcjonowania systemu finansowego oraz zwiększył się stopień swobodnego przepływu kapitału i możliwości prowadzenia spekulacji na międzynarodowych rynkach finansowych ${ }^{16}$.

Źródeł finansyzacji upatruje się także w emisji quasi-pieniądza przez prywatne banki komercyjne ${ }^{17}$. Oddanie przez państwo prawa emisji pieniądza bankom prywatnym wraz z deregulacja systemu finansowego spowodowało powstanie olbrzymich korporacji finansowych ${ }^{18}$, które celem zdobycia ponadprzeciętnych zysków nabrały zdolności do sterowania gospodarką i fazami cyklu koniunkturalnego. Oddanie emisji pieniądza prywatnym bankom spo-

${ }^{13}$ R. Barczyk et al., Banki a cykle koniunkturalne, Oficyna Wydawnicza SGH, Warszawa 2014, s. 26.

${ }^{14}$ D. Tomaskovic-Devey, K. H. Lin, Income inequality, economic rents and the financialization of the US economy, „American Sociological Review” 76, 2012, s. 539-559.

${ }^{15}$ L. Mesjasz, Kryzysy finansowe we współczesnej gospodarce światowej, w: S. Miklaszewski (red.), Międzynarodowe stosunki gospodarcze u progu XXI wieku, wyd. 2, Difin, Warszawa 2006 , s. 108-109.

16 W. Błasiak, Światowy kryzys gospodarczy a globalna akumulacja kapitału, „Contemporary Economics" 4(2), 2010, s. 43-44.

${ }_{17}$ J. H. de Soto, Pieniqdz, kredyt bankowy i cykle koniunkturalne, Instytut von Misesa, Warszawa 2009; S. Hongbing, Wojna o pieniadz, Wydawnictwo Wektory, Bielany Wrocławskie 2011.

${ }_{18}$ M. Księżyk, Źródła i ekonomiczne skutki kryzysów finansowych, „Nierówności Społeczne a Wzrost Gospodarczy”, z. 30, WN UR, Rzeszów 2013, s. 5-24. 
wodowało także, że w krajach gospodarki rynkowej zaczęła obowiązywać na masową skalę zasada rozwoju gospodarczego napędzanego przez dług. Doszło w konsekwencji do implozji zadłużenia, która uruchomiła deflację, a deflacja - recesję $^{19}$.

Przyczyn i źródeł finansyzacji należy poszukiwać więc w procesie transformacji interesów sektora finansowego ${ }^{20}$. Implikuja one bowiem transformację struktury i funkcjonowania rynków finansowych, rozwiązań z zakresu polityki społeczno-gospodarczej, a także zachowań przedsiębiorstw. Te ogólne przyczyny finansyzacji nazywane są wiodącymi kanałami jej rozpowszechniania ${ }^{21}$, a pomiędzy nimi zachodzą interakcje oparte na mechanizmie sprzężenia zwrotnego. Do każdej z nich można ponadto dopisać listę przesłanek szczegółowych, co zostało zestawione w tabeli 1.

Ze względu na fakt, że finansyzacja traktowana jest jako długoterminowa tendencja do zmiany roli sfery finansowej w gospodarce ${ }^{22}$, jej najbardziej rozpoznawanymi i szeroko komentowanymi w ostatnich latach skutkami sa: zjawiska kryzysów finansowych, pojawianie się baniek spekulacyjnych w sferze finansowej (szerzej: występowanie zjawiska niestabilności finansowej), wzrost zysków z aktywności finansowej w zyskach ogółem, wzrost wartości długu (prywatnego i publicznego) w relacji do PKB, wzrost roli sektora finansowego (sektor FIRE - finance, insurance, and real estate) w aktywności gospodarczej, nadmierne nasycenie rynku instrumentami pochodnymi i toksycznymi, wzrost wartości transferów kapitału z podmiotów niefinansowych do sektora finansowego ${ }^{23}$.

Wpływu finansyzacji gospodarki na współczesny kryzys finansowy należy poszukiwać w błędnych decyzjach i interwencjach rządów oraz banków centralnych, odejścia od historycznych zasad ustalania stóp procentowych, mylnej diagnozy problemów na rynku kredytowym i w ten sposób niewłaściwego im przeciwdziałania poprzez koncentrację na poprawie płynności, a nie na ograniczaniu ryzyka ${ }^{24}$. Selektywne wsparcie niektórych instytucji finansowych i ich wierzycieli, bez jasnych i zrozumiałych reguł, ma również wpływ na zjawiska kryzysowe. Oddziaływanie finansyzacji na skalę i siłę współczesnych kryzysów finansowych jest metaforycznie określane przez porównanie tego procesu do wirusa HIV ukrytego w organizmie systemu ekonomicznego ${ }^{25}$.

${ }^{19}$ Ibidem, s. 16.

${ }^{20}$ T. I. Palley, Financialization: what it is and why it matters, „The Levy Economics Institute and Economics for Democratic and Open Societies Working Paper" nr 525, Washington D.C., 2007, s. 11-15.

${ }^{21}$ Ibidem, s. 11.

${ }^{22}$ M. Ratajczak, Finansyzacja..., s. 290.

${ }^{23}$ J. B. Foster, The Financialization of Capitalism, „Monthly Review” 58(11), 2007.

24 J. B. Taylor, Zrozumieć kryzys finansowy, WN PWN, Warszawa 2010, s. 99.

25 J. P. Duran-Ortiz, Financialization: the AIDS of economic system, „Ensayos de Economia” 2014, nr 44, s. 55-73. 


\section{Tabela 1}

Ogólne i szczegółowe przyczyny finansyzacji

\begin{tabular}{|c|c|}
\hline Przyczyna ogólna & Przyczyny szczegółowe \\
\hline $\begin{array}{l}\text { Zmiany w strukturze } \\
\text { i działaniu rynków } \\
\text { finansowych }\end{array}$ & 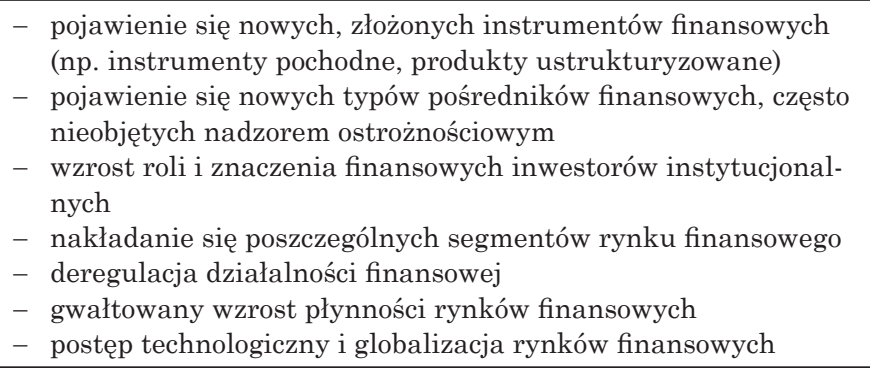 \\
\hline $\begin{array}{l}\text { Rozwiązania z zakresu } \\
\text { polityki społeczno- } \\
\text {-gospodarczej }\end{array}$ & $\begin{array}{l}\text { - polityka stymulowania globalizacji m.in. przez: zwiększenie } \\
\text { swobody przepływów kapitałowych, deregulację systemów finan- } \\
\text { sowych } \\
\text { - forsowanie koncepcji ograniczonego państwa, m.in. przez: odej- } \\
\text { ście od doktryny państwa dobrobytu i interwencjonizmu gospo- } \\
\text { darczego, prywatyzację, zmiany w systemach emerytalnych } \\
\text { - wspieranie elastyczności rynku pracy, m.in. przez: osłabianie } \\
\text { roli związków zawodowych, ograniczenia wysokości płacy mini- } \\
\text { malnej, zasiłków dla bezrobotnych, ochrony zatrudnienia } \\
\text { - nastawienie w polityce gospodarczej na stabilność poziomu cen, } \\
\text { m.in. przez: skupienie się na procesach dezinflacji, prowadzenie } \\
\text { polityki wysokich realnych stóp procentowych }\end{array}$ \\
\hline $\begin{array}{l}\text { Zmiany w zachowaniu } \\
\text { przedsiębiorstw } \\
\text { niefinansowych }\end{array}$ & $\begin{array}{l}\text { - wprowadzanie koncepcji zarządzania wartością dla właścicieli } \\
\text { - presja inwestorów na generowanie przez przedsiębiorstwa wyso- } \\
\text { kich stóp zwrotu w krótkim okresie } \\
\text { - wykorzystywanie na szeroką skalę innowacji finansowych, co } \\
\text { uzależnia przedsiębiorstwa od instytucji finansowych i zwiększa } \\
\text { ryzyko } \\
\text { - wzrost roli właścicieli finansowych, nieangażujących się aktyw- } \\
\text { nie w długookresowy rozwój działalności przedsiębiorstw } \\
\text { - prowadzenie polityki kapitałowej niezgodnej z teorią hierar- } \\
\text { chii źródeł finansowania, polegające na upowszechnieniu się } \\
\text { w przedsiębiorstwach finansowania zewnętrznego, opartego } \\
\text { głównie na mniej bezpiecznym długu } \\
\text { - przeznaczanie wypracowanego kapitału wewnętrznego na wy- } \\
\text { płaty dywidend lub wykupy akcji }\end{array}$ \\
\hline
\end{tabular}

Źródło: opracowanie własne na podstawie: P. Marszałek, Finansyzacja-problemy i kontrowersje, Prace Naukowe Uniwersytetu Ekonomicznego we Wrocławiu, nr 247, Wrocław 2012, s. 223-225.

Mniejsza uwaga jest natomiast skupiana na ocenie długoterminowej polityki redystrybucji dochodów podmiotów ekonomicznych osiaganych w wyniku finansyzacji ich aktywności ${ }^{26}$. Ponieważ deprecjacja wartości kapitału inwestowanego w aktywa finansowe jest zazwyczaj większa w długim okresie niż

${ }^{26}$ G. Krippner, The financialization of American economy, „Socio-Economic Review” 2005, nr 3, s. $173-208$. 
kapitału alokowanego w aktywa rzeczowe, podmioty niefinansowe zmieniaja politykę inwestycyjna - nastawiaja się na osiaganie zysków z krótkoterminowych przedsięwzięć, a nie z projektów ukierunkowanych na zapewnienie wieloletniego wzrostu i rozwoju ${ }^{27}$. Jednocześnie od lat osiemdziesiątych XX w. odnotowuje się dynamiczny wzrost realnego poziomu wynagrodzeń $\mathrm{w}$ sektorze finansowym, co powoduje w konsekwencji migrację zatrudnienia z sektora realnego do finansowego i przynosi efekt silnej dyspersji wynagrodzeń w obu tych sektorach gospodarki ${ }^{28}$.

Finansyzacja zmienia także strukturę i funkcjonowanie rynków finansowych. Badania teoretyczne odnoszą się w tym przypadku m.in. do analizy wpływu finansyzacji (szczególnie dostępności do kredytów) na zmiany wyników makroekonomicznych i przebiegu cyklu koniunkturalnego. Należy w tym miejscu zwrócić uwagę na hipotezę niestabilności finansowej H. Minsky'ego ${ }^{29}$. Uważał on, że powstające „wyrafinowane” instytucje finansowe tworzą spekulacyjny popyt na pieniądz, zwiększają niepewność oraz podnosza koszty pozyskania kapitału ${ }^{30}$. Sposób finansowania aktywów staje się więc nieobojętny dla stabilności finansowej, co wynika $\mathrm{z}$ angażowania się podmiotów gospodarczych w coraz bardziej ryzykowne formy finansowania działalności. W miarę rozpowszechniania się problemów z obsługą pozyskanych obcych źródeł finansowania spada w konsekwencji wartość rynkowa aktywów finansowych ${ }^{31}$.

Skutkiem finansyzacji są również wysoki dług publiczny i deficyt budżetowy, wysokie bezrobocie i rozszerzanie się sfery ubóstwa ${ }^{32}$. Istotnym czynnikiem permanentnego deficytu budżetowego w warunkach finansyzacji gospodarki jest też ujemne saldo obrotów bieżących i dodatnie saldo rachunku finansowego ujmowane w bilansie płatniczym kraju.

W tabeli 2 przedstawiono systematykę wyodrębnionych w literaturze tematu licznych konsekwencji finansyzacji. Przyjęto w tym celu ich umowny podział na występujące w sferze mikro- i makroekonomicznej ${ }^{33}$. Ponadto należy zwrócić uwagę na fakt, że nie jest łatwo ustalić wszystkie zależności przyczynowo-skutkowe, co oznacza, że podane w tabeli 1 przyczyny i źródła finansyzacji mogą być także oceniane jako jej następstwa.

27 G. Epstein, Introduction: Financialization and the World Economy, w: G. Epstein (ed.), Financialization and the World Economy, Edward Elgar, Northampton-Cheltenham 2005, s. $3-16$.

${ }^{28}$ J. D. Rauh, S. N. Kaplan, Wall Street and Main Street: what contributes to the rise in the highest incomes?, „Review of Financial Studies” 23, 2010, s. 1004-1050.

${ }_{29}$ H. P. Minsky, The financial instability hypothesis, „The Levy Economics Institute of Bard College Working Paper", nr 74, 1992.

${ }^{30}$ L. Kąsek, M. Lubiński, Hyman Minsky - wczoraj i dziś, „Contemporary Economics” 4(1), 2010, s. 7.

${ }^{31}$ L. R. Wray, E. Tymoigne, Macroeconomics meets Hyman P. Minsky: the financial theory of investment, „Levy Economics Institute Working Paper”, nr 543, 2008.

32 M. Księżyk, op. cit., s. 16.

${ }^{33}$ Por. P. Marszałek, op. cit., s. 226-228. 
Tabela 2

Mikro- i makroekonomiczne konsekwencje finansyzacji

\begin{tabular}{|c|c|}
\hline Skutki dla sfery mikroekonomicznej & Skutki dla sfery makroekonomicznej \\
\hline $\begin{array}{l}\text { - } \text { skomplikowanie prowadzenia działalności } \\
\text { gospodarczej } \\
\text { - } \text { uzależnienie kondycji poszczególnych pod- } \\
\text { miotów ekonomicznych od zmiennej sytua- } \\
\text { cji na rynkach finansowych } \\
\text { - } \text { utrudnienie wyboru właściwych źródeł } \\
\text { finansowania i form lokowania oszczędno- } \\
\text { ści na skutek wzrostu stopnia złożoności } \\
\text { rynków i operacji finansowych } \\
\text { - } \\
\text { podejmowanie coraz bardziej ryzykownych } \\
\text { przedsięwzięć ekonomicznych } \\
\text { - przyspieszenie tempa życia gospodarczego } \\
\text { intensyfikujące poczucie niepewności }\end{array}$ & $\begin{array}{ll}\text { - } & \text { skomplikowanie instytucji nadzoru finan- } \\
& \text { sowego } \\
\text { - } & \text { trudności w egzekwowaniu przestrzegania } \\
& \text { przez instytucje finansowe norm ostroż- } \\
\text { nościowych } & \\
\text { - } & \text { uleganie dyktatowi rynków i instytucji } \\
& \text { finansowych } \\
\text { - } & \text { rosnący ciężar długu publicznego uzależ- } \\
& \text { niający rządy od środków pozyskiwanych } \\
& \text { na rynkach finansowych } \\
- & \text { pomoc publiczna instytucjom finansowym } \\
& \text { popadajacym w kłopoty finansowe } \\
\text { - } & \text { wzmożona pokusa nadużyć (moral hazard) } \\
- & \text { utrudnione prowadzenie polityki pienięż- } \\
& \text { nej z powodu zmian instytucjonalnych, co } \\
\text { obniża jej skuteczność }\end{array}$ \\
\hline
\end{tabular}

Źródło: opracowanie własne na podstawie: P. Marszałek, op. cit., s. 226-227.

Wyróżnione skutki finansyzacji znajdują w konsekwencji odzwierciedlenie w trzech zjawiskach: osłabienia wzrostu gospodarczego, zmiany kształtu i przebiegu cyklu koniunkturalnego oraz rosnącej podatności gospodarek na kryzysy finansowe ${ }^{34}$. W zakresie osłabienia wzrostu gospodarczego objawia się to zwiększeniem stopnia nierówności pomiędzy sektorami gospodarki, wolniejszą stopą wzrostu PKB oraz wyższą stopą bezrobocia ${ }^{35}$. Z kolei w przypadku cech nowego cyklu koniunkturalnego występują m.in.: deficyty handlowe (ujemne saldo obrotów bieżących bilansu płatniczego), niska inflacja (CPI) przy jednocześnie rosnącej wartości aktywów, rosnące zadłużenie przedsiębiorstw i gospodarstw domowych, powiększająca się rozpiętość dochodów podmiotów finansowych i niefinansowych oraz oderwanie wzrostu płac od wzrostu wydajności ${ }^{36}$.

\section{MIERNIKI FINANSYZACJI GOSPODARKI}

Przedstawione przyczyny i konsekwencje finansyzacji skutkują wyodrębnieniem szeregu miar oceny siły (skali) tego zjawiska ekonomicznego. Mierniki są liczne i zróżnicowane, zależne od zakresu prowadzonych badań, co powoduje, że finansyzacja jest identyfikowana w sposób fragmentaryczny ${ }^{37}$.

34 Ibidem, s. 227.

${ }^{35}$ J. Assa, op. cit., s. 35-39.

36 T. I. Palley, op. cit.

${ }_{37}$ P. Wiśniewski, Nowe miary finansjalizacji, w: J. Ostaszewski, E. Kosycarz (red.), Rozwój nauki o finansach. Stan obecny i pożqdane kierunki jej ewolucji, SGH, Warszawa 2014, s. 325. 
Na przykład w badaniach finansyzacji krajów OECD wykorzystano jedynie dwa mierniki, tj.: wytworzonej wartości dodanej przez sektor finansowy w relacji do wartości dodanej gospodarki oraz wielkości przeciętnego zatrudnienia $\mathrm{w}$ sektorze finansowym do całkowitego zatrudnienia w gospodarce ${ }^{38}$. Z kolei przy ocenie wpływu finansyzacji na powstanie współczesnego kryzysu finansowego analiza opiera się na mierniku udziału kredytów hipotecznych w PKB lub zadłużenia prywatnego $\mathrm{w}$ relacji do $\mathrm{PKB}^{39}$.

W celu prezentacji skali finansyzacji poszczególnych gospodarek należy wykorzystać kilka głównych mierników opartych na relacjach do PKB: nominalnej wartości obrotów na rynkach finansowych, wartość aktywów finansowych (sektora finansowego), udziału sektora finansowego oraz zadłużenia sektora prywatnego. Powinno się je uzupełnić statystykami związanymi z poziomem zatrudnienia, wynagrodzeniami, wielkością inwestycji i konsumpcji bieżącej, saldem obrotów bieżących oraz przepływów finansowych i kapitałowych, a także kształtowaniem się podaży pieniądza (agregat M2 lub M3).

Z kolei w przypadku oceny skali finansyzacji podmiotów (przedsiębiorstw i gospodarstw domowych) należy wykorzystać: udział dochodów (zysków) finansowych $\mathrm{w}$ dochodach (zyskach) ogółem, poziom zadłużenia w reakcji do wartości aktywów ogółem (poziom dźwigni finansowej), wielkość wypłat z zysku przedsiębiorstw do ich zysku ogółem oraz udział w aktywach podmiotów ekonomicznych gromadzonych przez nich aktywów o charakterze finansowym.

Analizowana w literaturze siła wpływu finansyzacji na zmiany zachowań gospodarstw domowych, przedsiębiorstw niefinansowych, sektora finansowego oraz funkcjonowania gospodarki globalnej oparta jest więc najczęściej na następujących miernikach ${ }^{40}$ :

a) finansyzacji gospodarstw domowych: zadłużenie gospodarstw domowych w relacji do PKB, w stosunku do zadłużenia ogółem podmiotów ekonomicznych, w relacji do poziomu konsumpcji oraz wielkość konsumpcji w stosunku do PKB;

b) finansyzacji przedsiębiorstw: udział aktywów finansowych w aktywach ogółem oraz zysków z działalności finansowej w relacji do zysków ogółem przedsiębiorstw niefinansowych, stosunek inwestycji przedsiębiorstw do poziomu ich ogólnego zadłużenia oraz w relacji do zysków ogółem;

c) finansyzacji sektora finansowego: kapitalizacja giełd i obrotów na rynkach finansowych w stosunku do PKB, liczba pozabankowych instytucji finansowych w stosunku do ogólnej liczby instytucji finansowych, dochody banków osiagane innymi kanałami niż spread w stopach kredytowej i depozytowej, stopień skłonności banków do udzielania kredytów gospodarstwom domowym i przedsiębiorstwom;

d) globalnych skutków finansyzacji: zmienność kursów walutowych, wielkość przepływów kapitałowych netto w relacji do PKB, kierunki przepływu kapitału, częstotliwość występowania kryzysów finansowych.

\footnotetext{
38 J. Assa, op. cit., s. 35-39.

${ }^{39}$ O. Jorda et al., The great mortgaging: housing finance, crises, and business cycles, „Federal Bank of San Francisco Working Paper Series”, nr 23, September 2014.

${ }^{40}$ E. Stockhammer, Financialization and the global economy, „Political Economy Research Institute, Working Paper", nr 240, November 2010.
} 


\section{ANALIZA FINANSYZACJI GOSPODAREK WYBRANYCH KRAJÓW EUROPY ŚRODKOWO-WSCHODNIEJ}

Biuro Gospodarki Światowej Instytutu Ekonomicznego Narodowego Banku Polskiego (BGŚ IE NBP) od szeregu lat prowadzi cykliczne analizy sytuacji gospodarczej w krajach EŚW. Uwzględnia w nich problemy makroekonomiczne dziesięciu państw regionu, tj. czterech z grupy wyszehradzkiej (Czechy, Polska, Słowacja i Węgry), trzech republik nadbałtyckich (Estonia, Litwa i Łotwa) oraz Bułgarii, Rumunii i Słowenii. W celu rozwinięcia analiz BGŚ IE NBP do oceny skali finansyzacji w krajach EŚW zostało wytypowanych pięć państw, a mianowicie: Czechy, Estonia, Polska, Słowacja i Węgry, uważanych za największe i najsilniejsze gospodarki regionu. Zarówno wybór tych krajów, jak i mierników oceny badanego zjawiska był implikowany również dostępnościa porównywalnych danych oraz objętością opracowania. Okres badawczy obją lata 1995-2012 (poza kilkoma wyjątkami). Analizę oparto na danych czastkowych pozyskanych z OECD, Banku Światowego oraz Eurostatu, na podstawie których obliczono następujace mierniki finansyzacji: udział sektorów gospodarki w wartości dodanej, udział zatrudnienia w sektorze finansowym do ogółu zatrudnionych, zadłużenie sektora prywatnego oraz dług publiczny w relacji do $\mathrm{PKB}$, kapitalizacja i obroty na giełdach w stosunku do $\mathrm{PKB}$, podaż pieniądza (agregat M2) do PKB oraz stopa inflacji (CPI).

Obserwowany w krajach zachodnich od kilku dziesięcioleci wzrost udziału sektora finansowego (FIRE) w wartości dodanej gospodarki, przy malejaccym udziale sektora wytwórczego, nie ma istotnego miejsca $\mathrm{w}$ grupie badanych państw EŚW. Zrównanie udziałów tych dwóch sektorów gospodarki nastapiło w USA pod koniec lat osiemdziesiatych XX w. i po tym okresie sukcesywnie zwiększało się rozwarcie między nimi na rzecz coraz silniejszego znaczenia sektora FIRE, który po 2000 r. obją średnio ok. $20 \%$ udziału w wartości dodanej, przy ok. $12 \%$ udziale sektora przetwórczego ${ }^{41}$. Łacznie w badanych krajach EŚW efekt ten wystapił dopiero w 2008 r. i był krótkotrwały. Od 2010 r. udział sektora wytwórczego w wartości dodanej jest ponownie większy niż sektora FIRE (wykres 1). Oczywiście w poszczególnych państwach analizowanego regionu sytuacja ta kształtuje się odmiennie (tab. 3). Skutek finansyzacji ocenianej tym miernikiem wystapił najwcześniej w Estonii (1996 r.) i był trwały do końca okresu objętego badaniem, najpóźniej zaś - na Węgrzech i Słowacji (odpowiednio lata 2009-2011 oraz 2009). Efektu tego w ogóle nie zaobserwowano w Czechach. W Polsce większy udział sektora FIRE w wartości dodanej gospodarki miał miejsce dwukrotnie: przed akcesją naszego kraju do Unii Europejskiej (lata 2000-2003) oraz w 2010 r. Mimo różnic w poszczególnych państwach regionu, można jednak ostrożnie wnioskować o stopniowo rosnącej roli sektora FIRE w tworzeniu wartości dodanej, choć skala finansyzacji analizowanych gospodarek jest niewielka, a udziały w wartości dodanej sektora wytwórczego i FIRE są porównywalne w poszczególnych krajach.

\footnotetext{
${ }^{41}$ J. P. Duran Ortiz, op. cit., s. 55-73.
} 
Tabela 3

Udział w wartości dodanej poszczególnych sektorów gospodarki w wybranych krajach Europy Środkowo-Wschodniej [w \%]

\begin{tabular}{|c|c|c|c|c|c|c|}
\hline \multicolumn{2}{|c|}{ Wyszczególnienie } & \multirow{2}{*}{ Czechy } & \multirow{2}{*}{ Estonia } & \multirow{2}{*}{ Węgry } & \multirow{2}{*}{ Polska } & \multirow{2}{*}{ Słowacja } \\
\hline Lata & Sektor & & & & & \\
\hline \multirow{2}{*}{1995} & FIRE & 15,91 & 18,41 & 17,16 & 11,98 & 17,01 \\
\hline & Wytwórczy & 23,01 & 19,90 & 21,30 & 20,20 & 25,00 \\
\hline \multirow{2}{*}{1996} & FIRE & 14,71 & 19,80 & 17,16 & 12,82 & 15,90 \\
\hline & Wytwórczy & 24,60 & 18,70 & 21,30 & 19,10 & 24,20 \\
\hline \multirow{2}{*}{1997} & FIRE & 14,38 & 20,17 & 17,89 & 14,44 & 16,08 \\
\hline & Wytwórczy & 25,70 & 19,20 & 22,90 & 19,20 & 22,00 \\
\hline \multirow{2}{*}{1998} & FIRE & 15,40 & 20,73 & 17,87 & 15,26 & 16,13 \\
\hline & Wytwórczy & 25,00 & 16,80 & 23,20 & 18,90 & 22,60 \\
\hline \multirow{2}{*}{1999} & FIRE & 15,40 & 22,15 & 18,16 & 16,19 & 16,37 \\
\hline & Wytwórczy & 25,00 & 16,10 & 22,60 & 18,20 & 20,40 \\
\hline \multirow{2}{*}{2000} & FIRE & 15,05 & 21,63 & 19,22 & 17,95 & 16,56 \\
\hline & Wytwórczy & 25,90 & 17,00 & 22,90 & 17,20 & 23,80 \\
\hline \multirow{2}{*}{2001} & FIRE & 15,22 & 21,87 & 19,19 & 17,65 & 16,48 \\
\hline & Wytwórczy & 25,90 & 17,70 & 22,20 & 15,80 & 24,40 \\
\hline \multirow{2}{*}{2002} & FIRE & 15,42 & 21,85 & 19,64 & 17,51 & 18,46 \\
\hline & Wytwórczy & 24,60 & 17,40 & 21,30 & 15,50 & 21,80 \\
\hline \multirow{2}{*}{2003} & FIRE & 15,84 & 21,29 & 19,86 & 17,53 & 17,29 \\
\hline & Wytwórczy & 23,90 & 17,40 & 21,60 & 16,90 & 22,70 \\
\hline \multirow{2}{*}{2004} & FIRE & 15,59 & 21,49 & 19,74 & 16,81 & 16,88 \\
\hline & Wytwórczy & 25,30 & 16,70 & 22,20 & 18,30 & 23,30 \\
\hline \multirow{2}{*}{2005} & FIRE & 15,83 & 21,86 & 20,33 & 17,12 & 16,73 \\
\hline & Wytwórczy & 25,50 & 16,50 & 22,30 & 17,80 & 23,30 \\
\hline \multirow{2}{*}{2006} & FIRE & 15,73 & 22,15 & 20,74 & 17,30 & 16,55 \\
\hline & Wytwórczy & 25,60 & 16,50 & 22,80 & 18,00 & 23,30 \\
\hline \multirow{2}{*}{2007} & FIRE & 16,28 & 22,23 & 20,34 & 17,91 & 16,13 \\
\hline & Wytwórczy & 25,70 & 16,00 & 22,10 & 18,00 & 23,20 \\
\hline \multirow{2}{*}{2008} & FIRE & 17,78 & 22,80 & 20,65 & 18,23 & 16,38 \\
\hline & Wytwórczy & 24,30 & 15,70 & 21,60 & 17,70 & 22,40 \\
\hline \multirow{2}{*}{2009} & FIRE & 18,81 & 24,14 & 22,31 & 16,62 & 18,04 \\
\hline & Wytwórczy & 22,60 & 14,20 & 20,10 & 18,00 & 17,80 \\
\hline \multirow{2}{*}{2010} & FIRE & 19,00 & 23,28 & 22,15 & 16,92 & 17,69 \\
\hline & Wytwórczy & 23,00 & 15,90 & 21,90 & 16,80 & 21,00 \\
\hline \multirow{2}{*}{2011} & FIRE & 18,48 & 23,34 & 21,88 & 16,96 & 17,92 \\
\hline & Wytwórczy & 24,00 & 16,40 & 22,20 & 17,40 & 21,50 \\
\hline \multirow{2}{*}{2012} & FIRE & 18,33 & 23,30 & 21,77 & 17,23 & 18,31 \\
\hline & Wytwórczy & 24,70 & 15,40 & 22,70 & 17,30 & 21,70 \\
\hline
\end{tabular}

Źródło: opracowanie własne na podstawie danych OECD. 


\section{Wykres 1}

Skumulowany udział poszczególnych sektorów w wartości dodanej w badanych krajach [w \%]

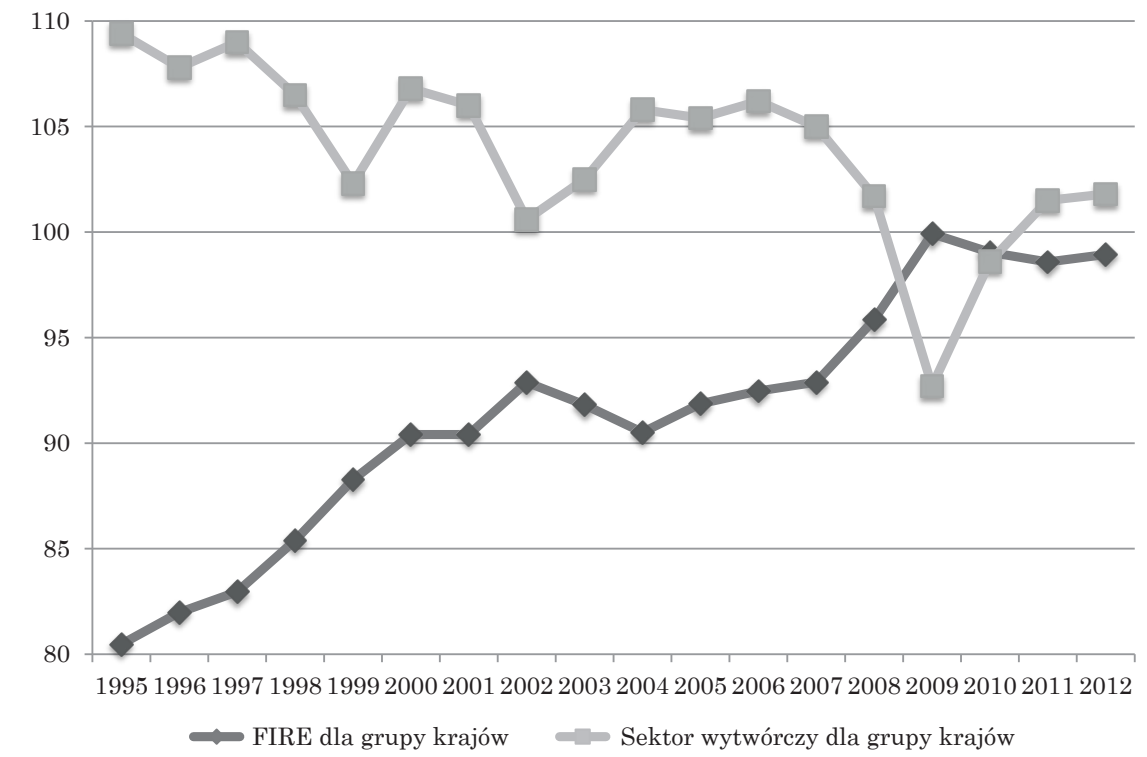

Źródło: opracowanie własne na podstawie danych OECD.

Spośród analizowanych krajów tylko Estonia i Węgry przekroczyły 20\% udział wartości dodanej sektora finansowego w wartości dodanej ogółem, tj. próg graniczny przyjęty w badaniach dla krajów OECD ${ }^{42}$ (wykres 2).

\section{Wykres 2}

Udział sektora FIRE w wartości dodanej gospodarki [w \%]

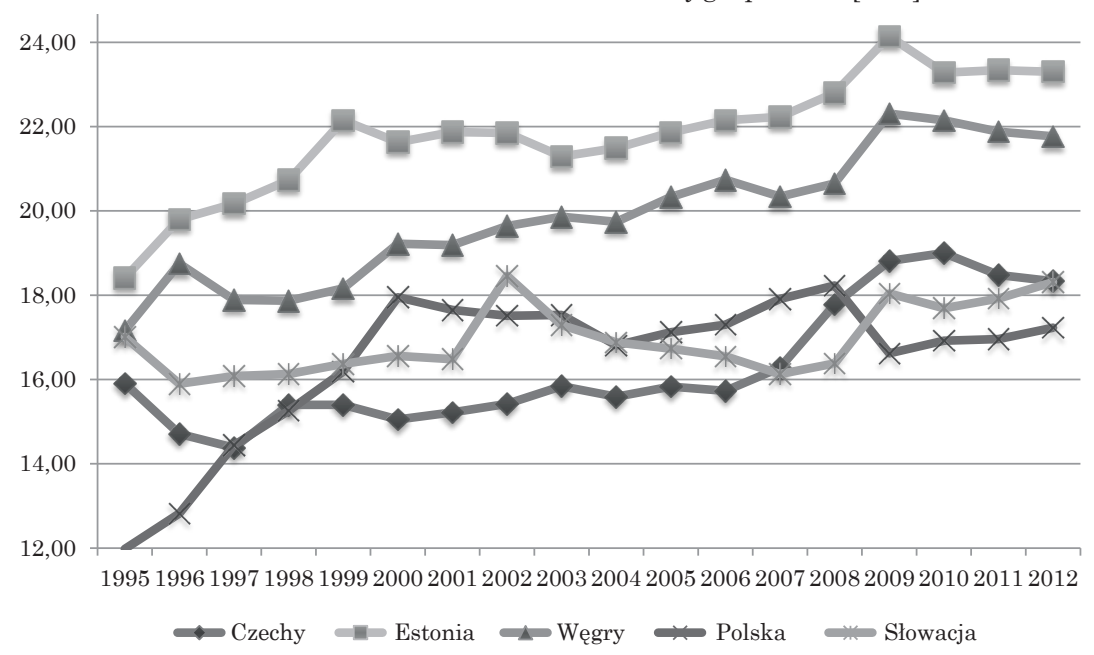

Źródło: opracowanie własne na podstawie danych OECD.

\footnotetext{
${ }^{42}$ Por. J. Assa, op. cit.
} 
Potwierdzeniem tezy o stopniowo rosnącej finansyzacji gospodarek krajów EŚW jest zaobserwowane zjawisko zwiększającego się udziału zatrudnionych w sektorze finansowym w relacji do ogółu zatrudnionych w gospodarce (wykres 3). Największą zmianę w rozpatrywanym okresie odnotowały Czechy, gdzie udział ten zwiększył się o ok. 1,5 raza. Jednakże we wszystkich analizowanych państwach udział zatrudnionych w sektorze finansowym w relacji do ogółu zatrudnionych jest na relatywnie niskim poziomie ('średnio ok. 3,5\% w badanym okresie) w porównaniu z sytuacją w najbardziej rozwiniętych krajach OECD (średnio na poziomie ok. 15\% w 2008 r.).

\section{Wykres 3}

Udział zatrudnionych w sektorze finansowym do ogółem liczby zatrudnionych [w \%]

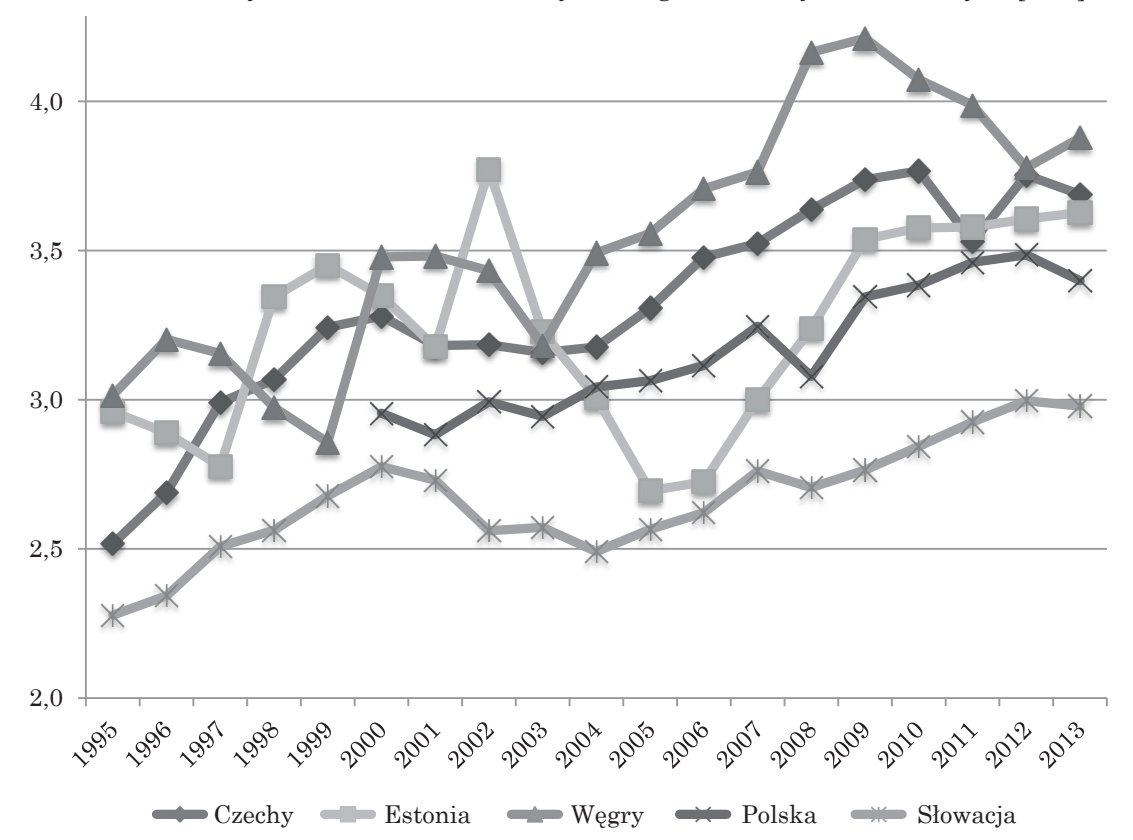

Źródło: opracowanie własne na podstawie danych OECD.

Inną miara, która ocenia poziom finansyzacji gospodarki, jest rosnące zadłużenie sektora prywatnego oraz wzrost długu publicznego w relacji do PKB. Skala zadłużenia sektora prywatnego zaprezentowana jest na wykresie 4, a długu publicznego - 5 .

$\mathrm{Z}$ perspektywy miernika zadłużenia prywatnego w relacji do PKB można stwierdzić, iż to Estonia i Węgry są państwami regionu o największym poziomie finansyzacji. System finansowy obu tych krajów kreuje średnio w rozpatrywanym czasie 1,85 jednostek kredytu na jednostkę PKB. Najniższy poziom tego wskaźnika jest w Polsce $(1,15)$ i na Słowacji $(1,14)$. Dług publiczny jako procent PKB jest również największy na Węgrzech (ok. 80\% PKB). Natomiast w Estonii jest najmniejszy (ok. 10\% PKB). Silną tendencję wzrostową wykazuje z kolei na Słowacji. 


\section{Wykres 4}

Zadłużenie sektora prywatnego w relacji do PKB w wybranych krajach [w \%]

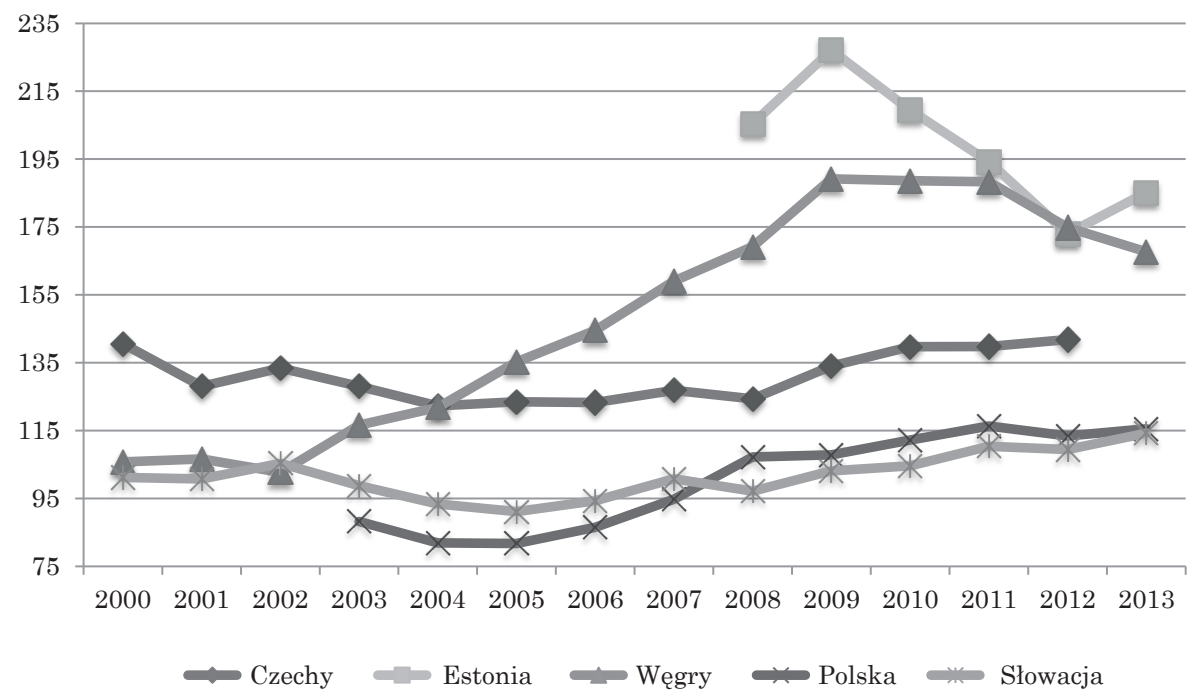

Źródło: opracowanie własne na podstawie danych OECD.

\section{Wykres 5}

Dług publiczny do PKB [w \%]

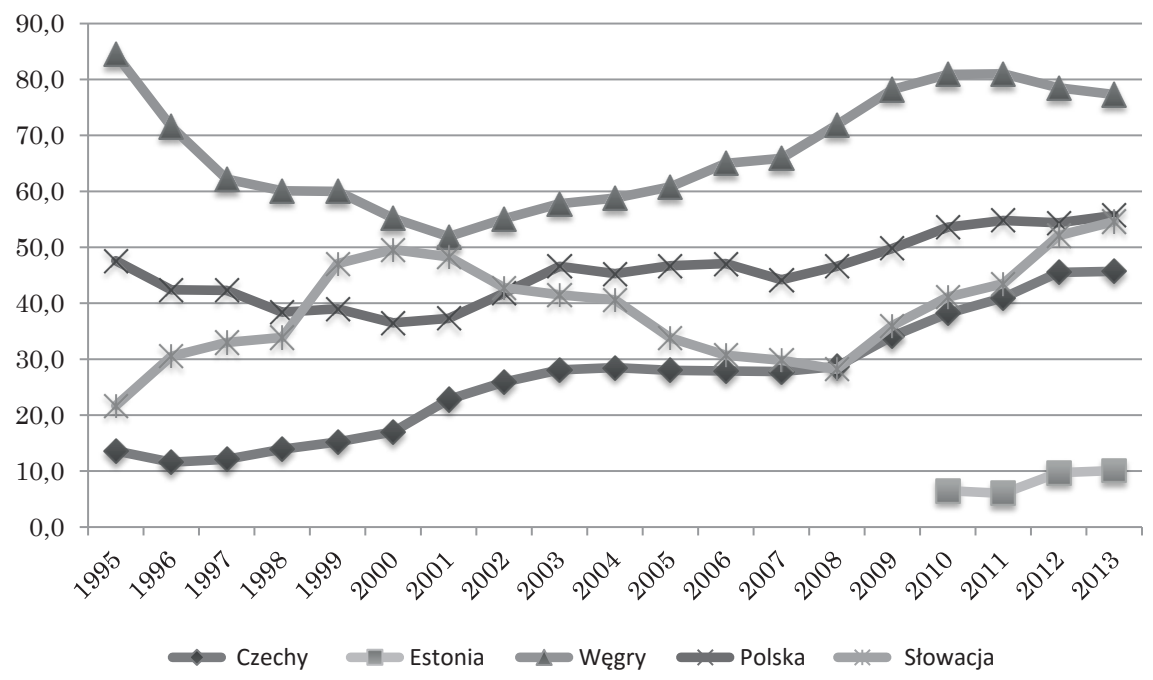

Źródło: opracowanie własne na podstawie danych Eurostatu. 
W grupie analizowanych krajów EŚW funkcjonuje zorientowany na banki, a nie rynkowy model systemu finansowego, co skutkuje sposobami i miejscami pozyskiwania kapitału przez podmioty niefinansowe. Stąd wskaźnik kapitalizacji rynkowej w relacji do PKB (wykres 6) jest na niskim poziomie w porównaniu z krajami Europy Zachodniej, czy USA, gdzie kapitalizacja giełdowa wzrosła z 58\% PKB w 1988 r. do $383 \%$ w $2008^{43}$. Można również zaobserwować wyraźna zależność koniunktury na rynku kapitałowym od koniunktury ogólnogospodarczej. We wszystkich analizowanych krajach wzrost ryzyka finansowego spowodowanego symptomami kryzysu wywołał istotny spadek kapitalizacji na giełdach papierów wartościowych.

Wykres 6

Kapitalizacja rynkowa do PKB [w \%]

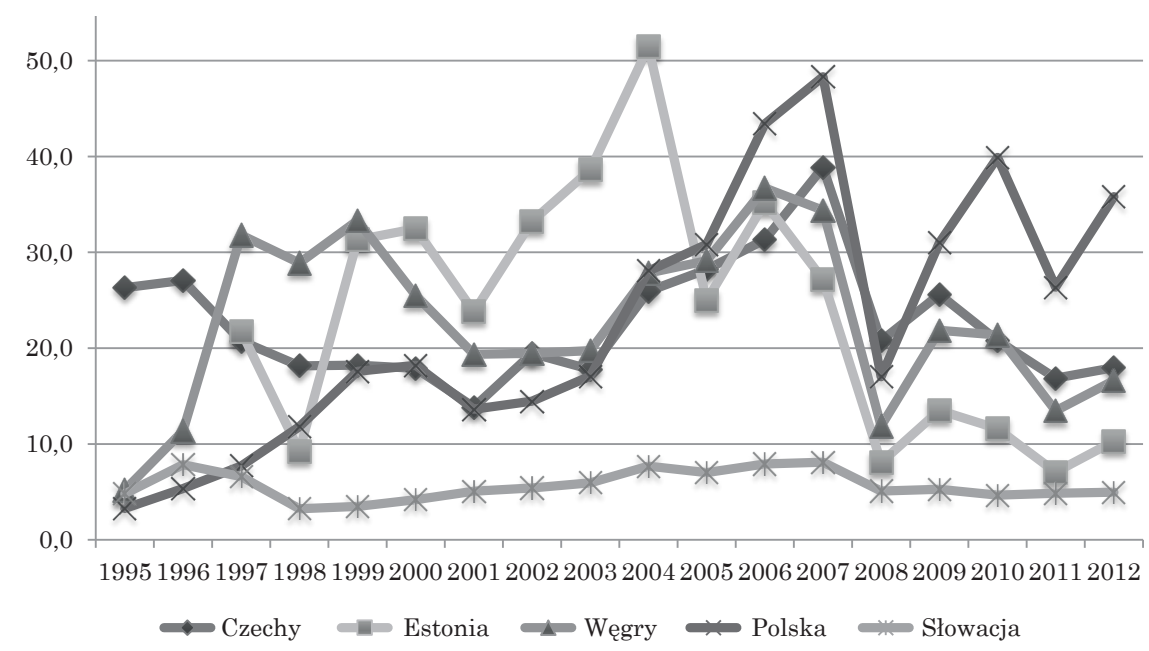

Źródło: opracowanie własne na podstawie danych Banku Światowego.

Przypadek Polski odstaje od pozostałych państw regionu. Współczynnik kapitalizacji rynkowej do PKB jest w ostatnich latach w naszym kraju na poziomie prawie dwukrotnie wyższym niż w pozostałych badanych państwach, co pozwala wnioskować o znacznym uzależnieniu rozwoju naszej gospodarki od kształtowania się sytuacji na rynku kapitałowym i w konsekwencji o wysokim stopniu jej ufinansowienia. Zgodnie z opiniami wyrażanymi w cytowanej literaturze tematu wskaźnik przekraczający $40 \%$ wskazuje bowiem na istotność giełdy w strukturze gospodarki kraju oraz na silny wzrost znaczenia ryn$\mathrm{ku}$ finansowego dla jej rozwoju.

Co ciekawe, ekspansja rynku kapitałowego w Polsce dzieje się w okresie malejących stóp procentowych, a tym samym zwiększania się dostępności kre-

\footnotetext{
${ }^{43}$ E. Stockhammer, op. cit.
} 
dytu jako źródła kapitału, co notabene uznawane jest za jedną z głównych przyczyn finansyzacji i wzrostu udziału sektora finansowego w gospodarce. W tym przypadku przewaga cenowa kapitału giełdowego schodzi na dalszy plan. Wytłumaczeniem wzrostu wskaźnika udziału kapitalizacji giełdowej w PKB jest więc postępująca finansyzacja wywołana inflacją pieniądza. Można ją rozumieć dosłownie jako wzrost podaży pieniądza (wykres 8 ), a także jako wzrost wolnych środków finansowych gospodarstw domowych i przedsiębiorstw. Ten ostatni aspekt wiąże się również ze zwiększeniem atrakcyjności lokowania środków w aktywa finansowe względem spadku zainteresowania inwestycjami rzeczowymi z powodu niższych stóp zwrotu osiaganych z inwestycji w tę druga grupę aktywów. Wartość aktywów finansowych w relacji do światowego PKB wynosiła $312 \%$ w 2012 r., choć najwyższy poziom równy $355 \%$ wskaźnik ten osiagnął w 2007 r. ${ }^{44}$ Tendencja ta ma także związek ze skracaniem horyzontu okresu inwestycji - z długoterminowych na krótkoterminowe (spekulacyjne). To ostatnie zjawisko jest nie tylko efektem, ale również przyczyną postępującej finansyzacji ${ }^{45} \mathrm{i}$ wiąże się ze wzrostem obrotów na rynku kapitałowym (wykres 7).

\section{Wykres 7}

Obroty na rynku kapitałowym w relacji do PKB [w \%]

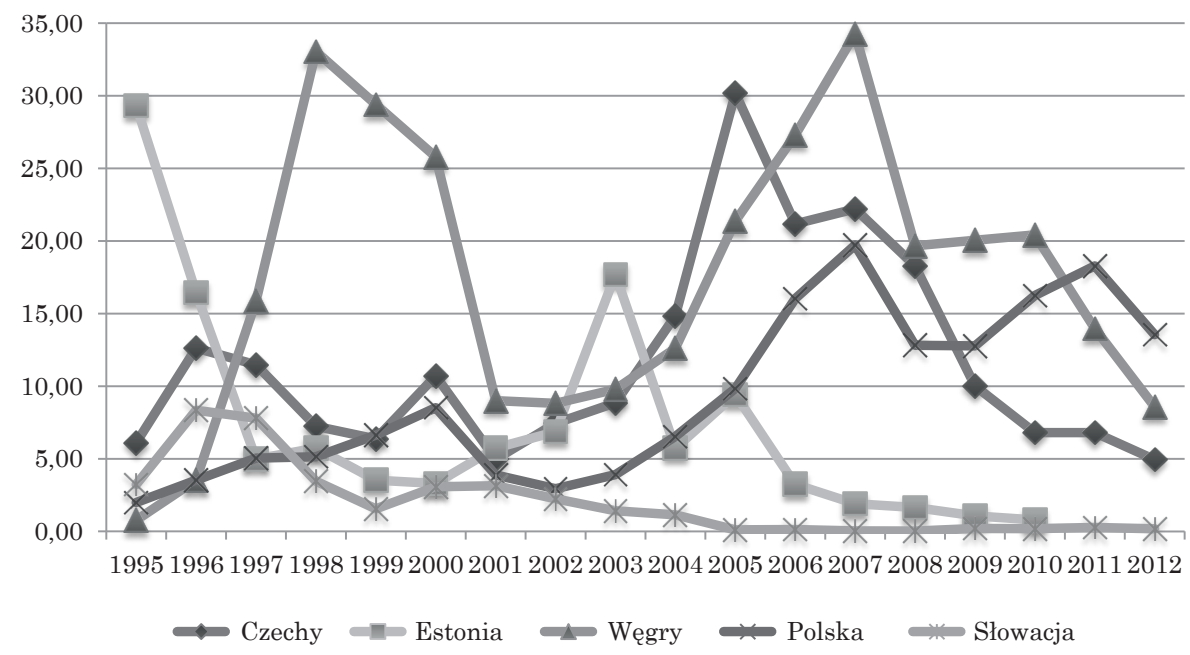

Źródło: opracowanie własne na podstawie danych Banku Światowego.

W krajach EŚW wzrost obrotów na rynku kapitałowym był szczególnie silny w pierwszej dekadzie XXI w., do załamania wywołanego globalnym kryzysem finansowym. W Czechach i na Węgrzech obroty na rynku kapitałowym sięgnęły $30 \%$, a w Polsce - 20\% PKB. Mimo tego rezultat ten jest nieporów-

${ }^{44}$ E. Gostomski, Finansyzacja w gospodarce światowej, „International Business and Global Economy" 2014, nr 33, s. 306.

45 J. Toporowski, op. cit., s. 9. 
nywalnie słabszy niż w gospodarce USA, gdzie na początku bieżącego wieku udział w PKB obrotów na rynku kapitałowym wynosił ok. 50\% ${ }^{46}$.

Analiza danych przedstawionych na wykresie 8 pozwala z kolei zaobserwować regularny wzrost podaży pieniądza (agregat M2) we wszystkich analizowanych krajach.

\section{Wykres 8}

Agregat pieniężny M2 do PKB [w \%]

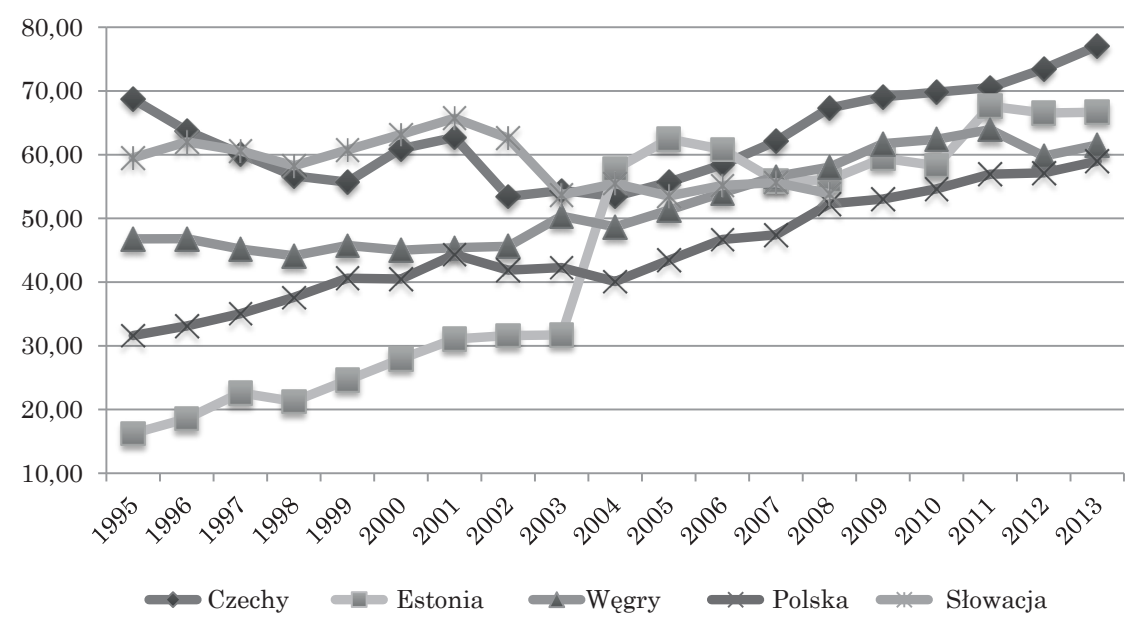

Źródło: opracowanie własne na podstawie danych Banku Światowego.

Wykres 9

Stopa inflacji [CPI, w \%]

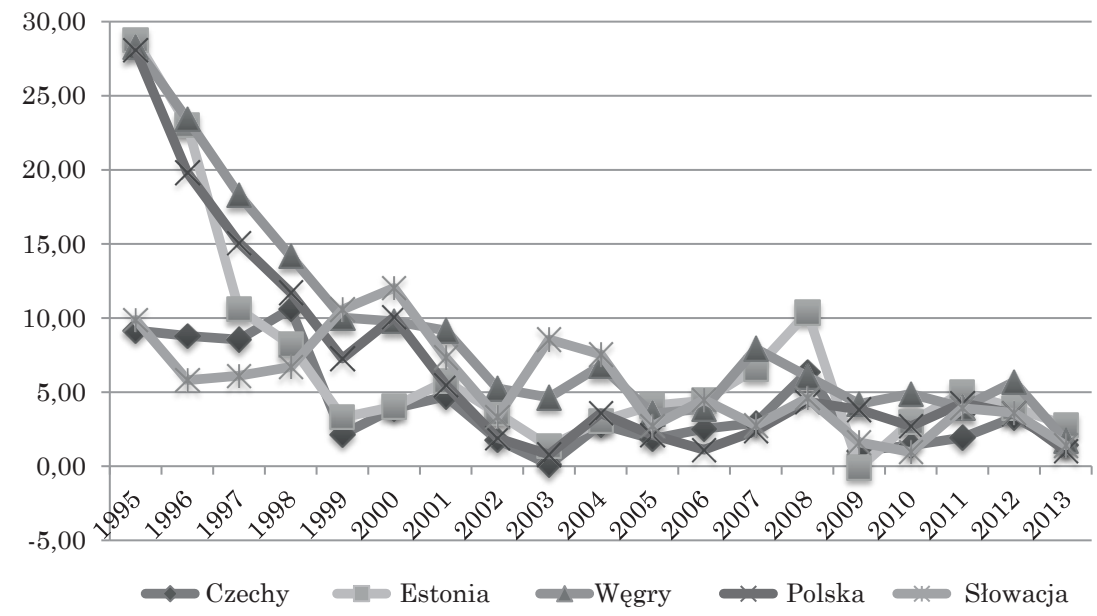

Źródło: opracowanie własne na podstawie danych Banku Światowego.

${ }^{46}$ J. Żyżyński, Neoliberalizm jako strukturalna przyczyna kryzysu a poszukiwanie dróg naprawy, „Ekonomista” 2009, nr 2, s. 174. 


\section{Wykres 10}

Wskaźnik cen akcji dla wybranych krajów Europy Środkowo-Wschodniej [ogółem, 2010=100]

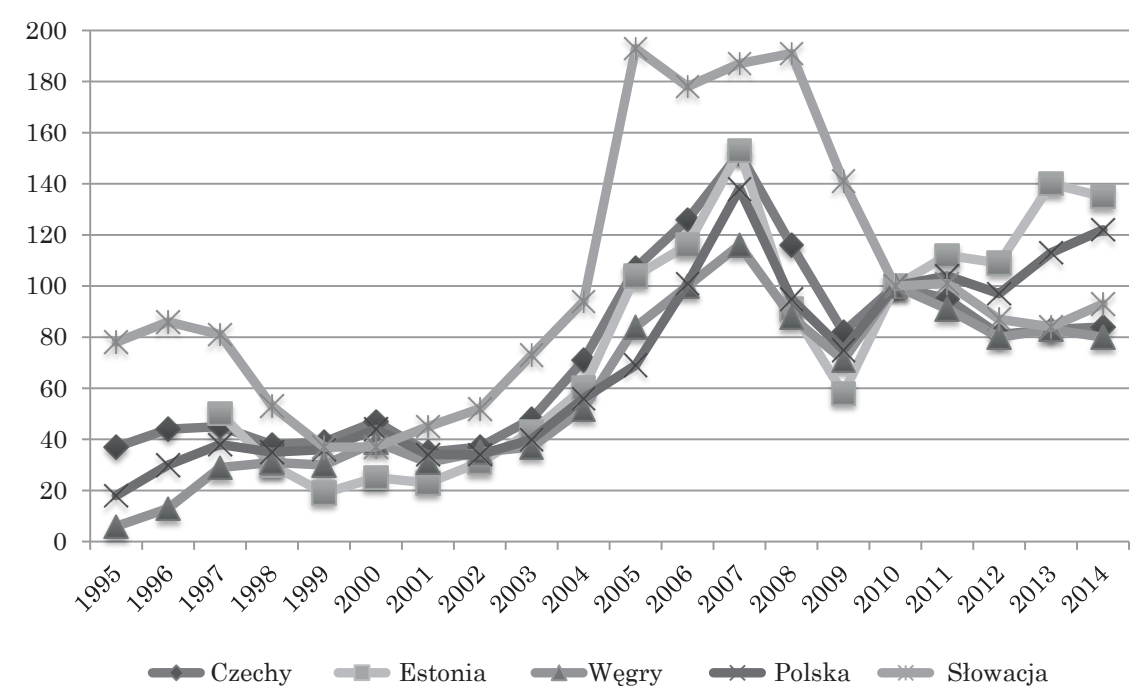

Źródło: OECD (2015), Share prices (indicator). DOI: 10.1787/6ad82f42-en [dostęp: 20.03.2015].

Kapitał finansowy w analizowanych krajach rośnie. Wynika to z powiększania się zasobów pieniądza utrzymywanego z motywów spekulacyjnego i ostrożnościowego, przy ograniczaniu jego roli jako płynnego aktywa niezbędnego do wykorzystania z motywu transakcyjnego. O te właśnie środki konkurują sektor bankowy i sektor giełdowy.

Niska i malejąca inflacja (CPI), a także niskie i malejące realne stopy procentowe przy wzroście wcześniej omawianych mierników kapitalizacji rynkowej i obrotów na giełdach w relacji do PKB potwierdzają zwiększanie się stopnia finansyzacji analizowanych gospodarek i świadczą o nasilaniu się tego zjawiska. Wywołuje to przesunięcie środków pieniężnych z banków - oferujących niskie stopy zwrotu - w kierunku ich alokacji $\mathrm{w}$ różne instrumenty finansowe, szczególnie akcje spółek, których wartości w konsekwencji rosna (wykres 10).

\section{ZAKOŃCZENIE}

Wykonane badanie wybranych gospodarek krajów EŚW wskazuje na występowanie różnic $\mathrm{w}$ ocenie skali ich finansyzacji w zależności od przyjętego miernika. Jednocześnie należy stwierdzić, że rozpatrując zagadnienie $\mathrm{w}$ porównaniu z wynikami osiaganymi przez gospodarki USA i państw Europy Zachodniej, uprawniona jest teza, że skala finansyzacji w tej części Europy jest relatywnie niewielka. Jedna z przyczyn takiego stanu rzeczy jest zorientowa- 
ny na banki, a nie rynkowy model systemu finansowego w analizowanych krajach. W konsekwencji udział zatrudnionych w sektorze finansowym w relacji do ogółu zatrudnionych w tej grupie państw zaliczanych do emerging markets jest na relatywnie niskim poziomie w porównaniu z najbardziej rozwiniętymi gospodarkami.

Tabela 4

Skala finansyzacji w wybranych krajach Europy Środkowo-Wschodniej na podstawie wyników wykorzystanych mierników w ostatnim roku okresu analizy

\begin{tabular}{|c|c|c|c|c|c|}
\hline Wskaźniki finansyzacji & Czechy & Estonia & Węgry & Polska & Słowacja \\
\hline $\begin{array}{l}\text { Udział sektora FIRE w wartości } \\
\text { dodanej gospodarki }\end{array}$ & 3 & 5 & 4 & 1 & 2 \\
\hline $\begin{array}{l}\text { Udział zatrudnionych } \\
\text { w sektorze finansowym do ogółu } \\
\text { zatrudnionych }\end{array}$ & 4 & 3 & 5 & 2 & 1 \\
\hline $\begin{array}{l}\text { Zadłużenie sektora prywatnego/ } \\
\text { PKB }\end{array}$ & 3 & 5 & 4 & 2 & 1 \\
\hline Dług publiczny/PKB & 3 & 1 & 5 & 4 & 2 \\
\hline Kapitalizacja rynkowa/PKB & 4 & 2 & 3 & 5 & 1 \\
\hline Podaż pieniądza (M2)/PKB & 5 & 4 & 3 & 2 & 1 \\
\hline Inflacja & 3 & 1 & 2 & 5 & 4 \\
\hline Wskaźnik cen akcji & 2 & 5 & 1 & 4 & 3 \\
\hline Suma & 27 & 26 & 27 & 25 & 15 \\
\hline Średnia ocen & 3,375 & 3,250 & 3,375 & 3,125 & 1,875 \\
\hline
\end{tabular}

Źródło: opracowanie własne.

Brak tak dużej skali ukredytowienia w badanych państwach może być wynikiem dużo bardziej szczelnych i restrykcyjnych regulacji sektora finansowego. W efekcie ten relatywnie niski poziom ufinansowienia w krajach EŚW, jak pokazuje historia zmian gospodarczych w ostatnich latach, stał się dla nich elementem łagodzącym występujące symptomy kryzysu - zmiana kształtu i przebieg cyklu koniunkturalnego były w nich mniej dotkliwe. Doprowadził on również do względnego bezpieczeństwa ekonomicznego w tej grupie krajów. Co ciekawe, pewne przejawy zjawiska finansyzacji charakterystyczne w krajach wysoko rozwiniętych nie występują w krajach EŚW lub występowały przez krótki czas. Tak się dzieje z udziałem wartości dodanej poszczególnych sektorów gospodarki. W USA czy w krajach zachodnich dominuje udział sektora finansowego, w krajach EŚW zaś ciągle istotne znaczenie ma sektor wytwórczy. Transformacja, która dokonuje się w badanych krajach od ok. 25 lat, przybliża model ich funkcjonowania do najbardziej rozwiniętych państw globu. Dzieje się to jednak nie zawsze idealnie zgodnie z wzorcem. Wszystkie kraje EŚW mają wspólną historię, która odciska piętno na ich uwa- 
runkowaniach społeczno-kulturowych, a tym samym powoduje tworzenie się systemu rynkowego w charakterystyczny dla nich sposób, z bagażem cech poprzedniego modelu gospodarczego. Niewykluczone, że te wspólne doświadczenia i podobne uwarunkowania, a także inny etap rozwoju ekonomicznego leżą u podstaw nieco odmiennego ukształtowania się systemu finansowego.

Ostateczna ocena stopnia finansyzacji badanych gospodarek polegała na uszeregowaniu wyników każdego z wykorzystanych mierników w kolejności od największego (ocena 5) do najmniejszego (ocena 1) dla każdego z rozpatrywanych krajów EŚW. Zostało to zestawione w tabeli 4.

Krajem najbardziej odpornym na zjawisko finansyzacji okazała się Słowacja. Czechy i Węgry cechują się zaś gospodarkami o największej i porównywalnej skali finansyzacji. W nieco mniejszym stopniu zjawisko to dotyka Estonię i Polskę, choć różnice punktowe w przyjętej metodologii nakazują jednak daleko idąca ostrożność w jednoznacznej interpretacji wyników, szczególnie gdy procesy finansyzacji zachodzą w badanych krajach z różnym natężeniem w poszczególnych latach.

Przeprowadzona analiza pozwoliła na określenie poziomu finansyzacji gospodarek wybranych krajów EŚW, co było celem tego opracowania. Skala tego zjawiska jest zasadniczo mniejsza niż w krajach wysoko rozwiniętych. Wydaje się, że aby jednoznacznie wskazać przyczyny tego stanu rzeczy, konieczne sa dalsze pogłębione badania. Na tym etapie można powiedzieć, że mniejsza deregulacja i liberalizacja rynku finansowego, która wystapiła w krajach EŚW, była w efekcie dobrodziejstwem i swoistym czynnikiem amortyzujaccym negatywny wpływ ostatniego kryzysu finansowego na gospodarki tych państw.

dr hab. Grzegorz Gotębiowski

Profesor Wyższej Szkoty Finansów i Zarzqdzania w Warszawie

g.golebiowski@vizja.pl

dr hab. Piotr Szczepankowski

Profesor Wyższej Szkoły Finansów i Zarzqdzania w Warszawie

szczepankowski@vizja.pl

\section{FINANCIALIZATION IN CENTRAL AND EASTERN EUROPEAN COUNTRIES}

Summary

The blurring boundary between the financial and real economy, as well as the growing autonomy of the financial sector have been observed since the late 1970s. This phenomenon has been referred to in literature as financialization. The article presents several definitions of the financialization process, which occupies an important place in the modern economic world. The paper presents the reasons, sources and effects of financialization, followed by a discussion on the right measures of that process. These measures are then used for an empirical study of the degree of financialization in selected Central and Eastern European countries. The analysis led to the conclusion that the scale of the financialization phenomenon in this part of Europe is relatively small, but not completely uniform in individual countries. The scale of financialization in the Czech Republic, Hungary, Estonia, and Poland should be assessed to be rather similar, while Slovak economy is the most resistant to the financialization process. 
